At Weybourn I hear that the sea broke through the beach and flooded the Constguards' cottages.

None of the fishermen can remember a single tide doing so much harm. I believe a yard is rather more than the estimated yearly loss of land. And Mr. Upscher informs me that he reckons his loss of land during the past sixty years to be thirty acres at the very least.

Grologicat Survey, Cromer, 14 th February, 1877.

Clement Reid.

THE TROPICAL FORESTS OF HAMP

SrR,- - I have no wish to enter into any discussion with Mr. Searles Wood, jun.; but he has, it seems to me, written to you upon a subject on which, notwithstanding his large store of geological knowledge, he appears to be quite unacquainted. The supposition, alluded to in my lecture at South Kensington, that oscillations of climate might partly account for the varied character of the Bagshot Floras, is partly based upon and supported by strong negative and some positive evidence, of alternating warmer and colder conditions, not glacial; contained not only in English Eocene, but all Tertiary beds throughout the world, although these seem to have escaped Mr. Wood's appreciation. No glacial conditions are necessary to explain anything connected with the Eocene Floras; but Mr. Wood cannot surely suppose that the Bagshot leaves from the London basin and those from Bournemouth and Alum Bay indicate an equal temperature; or that the Fauna of the Thanet sands, Woolwich beds, and London Clay, or the Bracklesham, Headon, Bembridge, and Hempstead beds do not make plain to us that the climatal conditions during the deposition of our Eocene series differed widely at each period.

The second hypothesis, that of the existence of a mean annual temperature which permitted the growth of sub-tropical and more temperate forms side by side, is supported by abundant evidence, and is the one by which Ettingshansen, and almost every continental geologist who has devoted himself to the study of Tertiary Floras, can best explain the universal admixture of these forms at that time in all our, at present, temperate climates. Mr. Searles V. Wood, jun., however, states that both these theories are "remote from the truth," and proceeds to make some extraordinary mis-statements in the process of giving what he believes to be the true explanation. After expressing the total thickness of these beds, which reach nearly 1000 feet, as " upwards of $200^{1}$ feet," he goes on to say that the vegetable remains have been drifted, and are not in sitú.

Mr. Wood can never have personally worked at these beds, or even examined collections made from them by others, or he could not have so failed to comprehend what he had seen.

He appears not to be at all aware of the published work and the conclusions of those who have studied these beds in England, or the similar leaf-bearing Eocene and Miocene beds abroad; neither can he have heard or read the statements made by me in my lecture, or in an appendix to it communicated to the Geologists' Association.

1 This was a Printer's error; Mr. Searles V. Wood, jun., correctly stated the thickness at 2000 feet, see his letter at p. 141 . We regret the mistake exceedingly. Edit. Geol. MaG. 
The leaves have never been drifted from afar; they are often still adhering to the twigs. The leaves are flat and perfect, rarely even rolled and crumpled, as dry leaves may be, if falling on a muddy surface; still more rarely have they fallen edgeways and been imbedded vertically. They are, moreover, not variously mixed, as they should be if they had been carried for any distance, but are found in local groups of species. For example, all the leaves of Castanea have been found in one clay patch, with Iriartea and Gleichenia; none of these have been found elsewhere. A trilobed leaf is peculiar to Studland ; the Alum Bay Aralia, the peculiar form of Proteacee, the great Ficus, and other leaves occur at Alum Bay only. Each little patch at Bournemouth is characterized by its own peculiar leaves. Such a distribution can only result from the proximity of the trees from which the leaves have fallen. The forms of most temperate aspect are best preserved, so that, to be logically applied, the Drift theory requires the palms, etc., to have been drifted upwards. To suppose that most delicate leaves could have been brought by torrents 400 miles from Mull or 200 miles from Wales, and spread out horizontally in thousands, without crease or crumple, on the coast of Hampshire, may be a feasible theory to Mr. Searles V. Wood, jun., but will not recommend itself to the majority of thinkers. But without invoking these lengthy voyages, the requisite height might have existed near at hand in the granite region of Devon, during the Eocene time. However this may be, so obviously simple an explanation as that the temperate forms grew on high ground and were drifted down and mingled with those growing on lower levels, bad of course escaped no worker on these or similar floras, and has been duly considered and abandoned by every one.

J. S. G GRDNER.

\section{IS THERE A BASE TO THE CARBONIFEROCS ROCKS IN TEESDALE?}

SIr,-Some years ago, when out on a geological tour, I crossed over the Pennine Chain from Appleby, in Westmoreland, to High Force in Upper Teesdale. My route was first along the Eden valley plain to High Cup Gill Beck; next up the side of this Gill to High Cup Nick, at the head of the Beck; thence across to Maize Beck, which is a tributary to the Tees, following down the south side of this beck to Caldron Snout, and continuing on from here down the side of the Tees to the old Pencil Mill, where my attention was arrested by observing the shale, here exposed, to have a striking resemblance to the Silurian shales which I had noticed at the foot of High Cup Gill, on the other side of the chain, and at other places in the Lake District, also on the east side of this district, in Wastdale Beck, near Shap Wells. The Carboniferous strata rise from the vicinity of the old Pencil Mill, in a westerly direction, on the line of the route just sketched, and crop ont on the west slope of the chain in High Cup Gill Beck, where there is to be met with one of the finest sections of the Carboniferous rocks in the North of England. In the lower part of this Gill there is a very thick section of 